\title{
HOW THE BLUE JAY GOT ITS NAME
}

The beginnings of the Blue Jay read like a fairy story. Let me tell it from the vantage point of a boy who was there.

More than half a century ago, World War I interrupted a young woman's botanical studies in England, Germany and Switzerland. Instead of completing her research studies after the war, Isabel $M$. Adams married a young Canadian soldier, Robert J. Priestly, on New Year's eve of 1918, and came to live in Canada. After residence in Calgary and Victoria, the young couple moved to Winnipeg in 1929, where Bob was desk editor with the Winnipeg Free Press. Isabel joined the botany section of the Manitoba Natural History Society, but discovered on society outings that members of the ornithology section, led by A. G. Lawrence, seemed to be having more fun. Mrs. Priestly began the study of birds as well as flowers, and continued both after moving to Yorkton in July 1935.

The following year, a nine-year-old boy in Yorkton received a copy of Birds of Canada by P. A. Taverner for his birthday. Two aunts had joined together to buy it, for three dollars was an unheard-of amount to spend on one book in depression times. Three years later, the boy encountered some birds he could not identify from the book. His father suggested that the boy go to.see Mrs. Priestly, now co-author of the weekly "Wild Life Corner" column in the Yorkton Enterprise. Mrs. Priestly at once recognized that he was describing immature American Goldfinches, which in fall look very different from the adults depicted in the Allan Brooks' painting in Taverner.

The next spring, the boy and several of his friends began regular weekly hikes around the "muskeg" on the western outskirts of Yorkton with Mrs. Priestly. After two years, Mrs. Priestly suggested that they type up a list of the species they had seen on these walks. The boy enthusiastically offered instead mimeograph the list, for he had lear ed to type while immobilized with fractured ankle in grade 5 , and now grade 9 was the operator of a sm mimeographing business that print the Rotary Club's weekly bulletin.

Mrs. Priestly decided to include a ditional records of interest within thirty-mile radius, with son historical notes from John Gunn Spirit Lake and from Frank Baines Crescent Lake. The list w mimeographed in July 1942, with "run" of 75 copies, thought by $M$ Priestly to be three times as many were needed. But she hadn't count on her old friend, A. G. Lawrence Winnipeg, who received a court copy of the rather pathetic little fi page list of 193 possible and hypothetical species. "Chickad Notes" \#1,114 on July 31 featured Yorkton list and advised readers send $10 \AA$ for a copy, "a model other clubs and for isolat observers."

Since Mr. Priestly was justly prc of his wife, and also happened to the Yorkton representative for Regina Leader-Post and the Sas toon Star-Phoenix, a long news st in both papers told of the pr. showered on Mrs. Priestly by the pert from Winnipeg. Further requ for the list poured in and a reprin became necessary.

Many purchasers of the list wi back to Mrs. Priestly. Judge Louit McKim of Melville sent a substar list of additional species; and Will Niven of Sheho, also at the edg the Yorkton area, sent other c ments. Maurice G. Street of Nipa and Steve A. Mann of Skull Ci wrote long letters to dis differences between the birdlif the north and southwest, respec ly, and that of the Yorkton area.

Mrs. Priestly decided that $t$ observations, too, should be tributed. She considered fir round-robin mailing of such let 


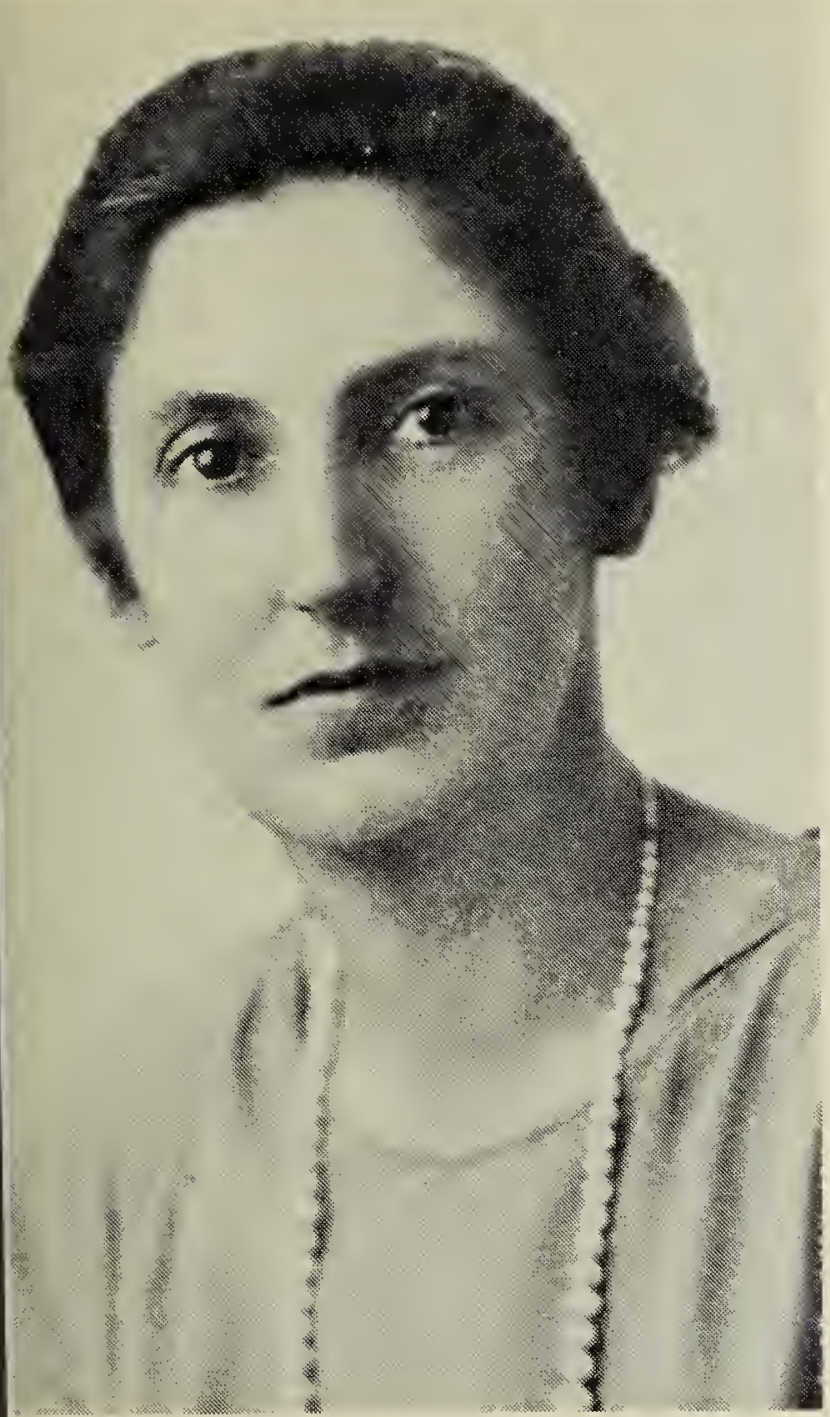

Isabel M. Priestly, born July 23, 1893, bury, Berks., England. Died April 23, 6, Yorkton, Saskatchewan. Named as of 23 outstanding Canadian women logists by Lorraine C. Smith, "Canadian men Natural Scientists - Why Not?", . Field-Nat. 90: 1-4, March 1976.

the boy suggested that these, too, Id be mimeographed. Mrs. Priesthen conceived the idea of an anI birdwatchers' newsletter and ided that such a project would uire a society to back it.

he organization meeting to disformation of a new society was September 11, 1942 at a private he with eight people present. re were only four adults - Mrs. J. oreman, Miss Ethel Lloyd, J. Tepas Mrs. Priestly. Harvey Beck, a high ol student just entering Grade 10, elected temporary chairman. A le 9 student, Vernon Barnes, e the motion that a Natural pry Society be formed. The boy named secretary-treasurer. The only student not elected to office was Ray Adams, then in grade 7. Harvey Beck and Vernon Barnes became directors, together with Ethel Lloyd, and Mrs. Prietsly was President of the new society.

The first proposal was to name the society the Northeastern Saskatchewan Natural History Society, for the Yorkton Enterprise referred to Yorkton as the hub of "Northeastern Saskatchewan", the most northeasterly settled area of the province. Mr. Jack Tepas strongly insisted that Yorkton was in the southern third of the province. Others wanted to call it the Saskatchewan Natural History Society, but Mrs. Priestly was sensitive to the fact that a Regina Natural History Society had been in existence for many years. By exclusion, the society became the Yorkton Natural History Society.

No time was lost in holding an executive meeting on September 15, to draft a circular which was mailed on September 17 to 63 prospective outof-town members. The membership fee was quoted at $25 \propto$ per year and a first issue was promised in two weeks time! The minutes of that first executive meeting noted that "as the allotted time was up, the meeting adjourned." In those days, high school students had to get to bed early!

The minutes of both meetings and the circular itself all failed to mention the name of this projected quarterly bulletin. However, the first issue in October carried the name Blue Jay on the masthead. Only in the fifth issue (Vol. 2, No. 1), did Mrs. Priestly explain that the name was chosen because" "Sammy Jay' was the 'roving reporter' of the Burgess Bedtime Stories world." It was her hope that the Blue Jay magazine would carry nature's message throughout Saskatchewan even as the blue jay in the Burgess stories carried news to all the birds and animals of the Green Forest and the Green Meadows.

Not surprisingly, the second annual meeting of September 24, 1943, showed a deficit of $\$ 9.40$ on expenditures of $\$ 59.50$ during the first year of 
operation. The minutes of that meeting noted that "a rather heated discussion then took place on the matter of raising the membership fee. It was pointed out that they could not be raised this year, as members had been informed in the Blue Jay that the fees would remain the same for the coming year." The membership fee was raised to $50 \uparrow$ one year later, even though the society had a balance on hand of $\$ 12.71$ after voting a $\$ 10$ honorarium to the secretarytreasurer, and purchasing a $\$ 4.75$ book as a token of their appreciation for Mrs. Priestly's work as president and editor. The benefits of an enlarging membership were becoming evident.

The Blue Jay made contact with people from all over Saskatchewan, most of whom didn't realize how many shared their interests. In addition to the names already mentioned, out-of-Yorkton contributors to volume 1 of the Blue Jay were: Dick Bird of Regina, Mrs. C. W. Cates of McLean, E. P. Coe of Wawota, H. Downing of Moosomin, R. M. Ferrie of North Battleford, John R. Garden of Wolseley, Mrs. John Hubbard of Grenfell, Miss E. Jones of Raymore, Dr. R. W. Kirkby of Prince Albert, Mrs. Marion Nixon of Wauchope, W. J. Orchard of Regina, Laurence B. Potter of Eastend, Dr. D. S. Rawson of Saskatoon, H. M. Rayner of Ituna, F. Rouse of Scott, J. Frank Roy of Tullis, LeRoy Simmons of Maymont, Arthur Ward of Burnham and J. H. Yerex of Clair.

Mrs. Priestly died April 23, 1946, soon after completing the 15th issue of the Blue Jay. The very last note in her diary was tor April 8, 1946, follows: "Lovely morning. Walke out along the tracks to pond on we road. Meadowlarks singing, junc everywhere, blue jays around the trees. Ponds frozen over, no ducks red-wings, just one Brewer's. On wi home, heard a Blue Jay singing. "*

Who would have predicted, fro its shaky start depending on a co catentation of improbable ci cumstances, that the Blue Jay wou develop quickly into a respected ar widely circulated regional public tion, the envy of many other areas $d$ this continent? Its ability to repd scientific data of importance, whi maintaining popular interest, is heritage from Mrs. Priestly, and $t$ tradition has been continued by $h$ successors, Cliff Shaw, Lloyd Ca michael, George Ledingham, $B$ Nero, and Bernie Gollop. A few pe ple of unusual talent and dedicatic have thus made the Blue Jay a succe Our best wishes go forward to t new editor, Gary Seib, to carry on $t$ tradition.

*As A. C. Bent says: "Comparatively $f$ observers are familiar with the song of blue jay ... his quiet solo ... is a potpot of faint whistles and various low, sw notes, some in phrasing and pit suggesting a robin's song - a mockingb might be singing, sotto voice." What appropriate last entry! May the "song" the Blue Jay long continue in $M$ Priestly's memory - C.S.H.

EDITOR'S NOTE: Most readers will h recognized at once that "the boy", n with greying sideburns and two marr children, is none other than the long-ti chairman of our Special Publications Co mittee, C. Stuart Houston.

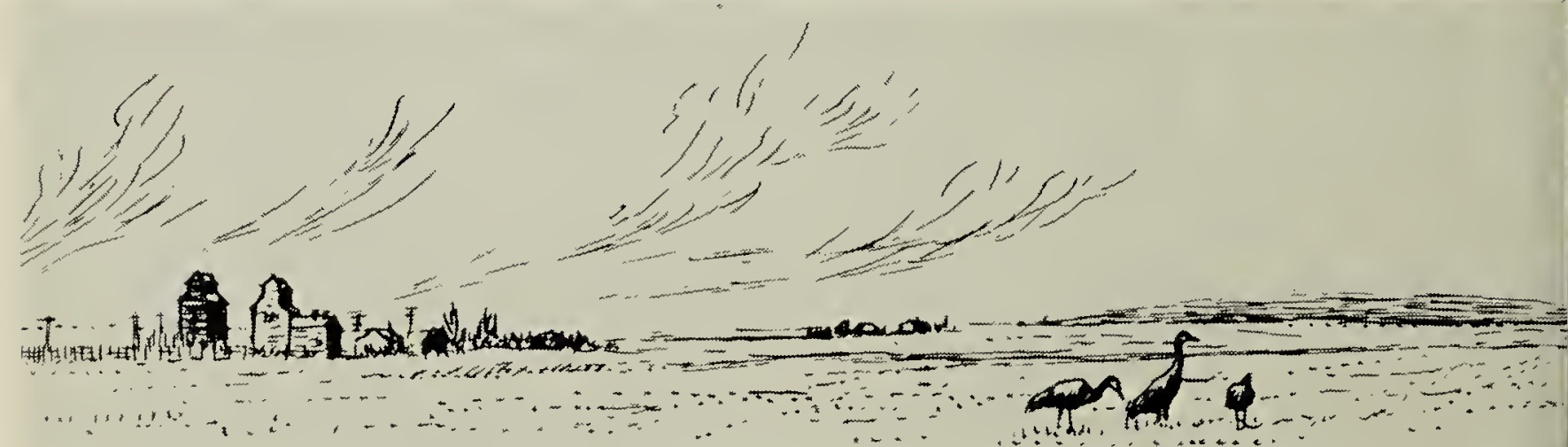

Fred Lahrn 